\title{
A Study on the Effects of Milling Strategy on Surface Roughness
}

\author{
Ayhan Etyemez $^{1 *}$ Aziz Baran ${ }^{2}$ \\ ${ }^{1}$ Nikken Turkey, Istanbul, Turkey \\ ${ }^{2}$ Metropolsoft, Istanbul, Turkey \\ *ayhan@nikken.com.tr \\ Received: 07 December 2018 \\ Accepted: 08 February 2019 \\ DOI: $10.18466 /$ cbayarfbe. 492270
}

\begin{abstract}
In this study, DIN 1.2344 hot work steel which was hardened at 51 HRC hardness value was processed by using high-speed milling technology, and different milling parameters with $6 \mathrm{~mm}$-diameter spherical endmill and the surface qualities which were obtained as a result of milling were examined. Axial and radial feed values, feed value per tooth and depth of cut were changed between the range of 0.05 and $0.1 \mathrm{~mm}$ and the rate of cutting was changed between the range of $485 \mathrm{rpm}$ and 4,000 rpm. These millings were carried out on material in the spherical form of which diameter was $21 \mathrm{~mm}$, and the central angle was $150^{\circ}$. Also, milling directions were processed in different ways as climb milling, conventional milling and bidirectional milling in experimental cuttings. Surface roughness was examined in directions with $15^{\circ}, 45^{\circ}, 75^{\circ}, 90^{\circ}, 105^{\circ}$, $135^{\circ}$ and $165^{\circ}$ central angles on the material which was processed. The best surface quality was achieved in regions with $15^{\circ}$ and $45^{\circ}$ angles.
\end{abstract}

Keywords: High-speed milling, Surface quality, Milling strategy.

\section{Introduction}

High-Speed Milling (HSM) technology of hard materials quickly also gets more advanced in parallel with the developments in tools and machine tools in the manufacturing sector. Concordantly, low work cost, manufacturing in a short span of time, minimum values of surface roughness as well as measurement accuracy are aimed to be achieved in mould making and mass production industries. HSM is one of the methods which will be used in achieving this target.

The aim of HSM is a high rate of machining $\left(\mathrm{mm}^{3} / \mathrm{min}\right)$, low cutting force and minimum vibration. Thin-walled sections can be processed through this method via simple coupling equipment. Moreover; surface roughness which can be achieved until the value of $0.1 \mu \mathrm{m}$ Roughness average $(\mathrm{Ra})$, reducing the milling times at important rates, machine tools being exposed to lower radial and axial forces, no damage on part surface, substantial decrease in the number of cutting tools which are used, chips to be easy disposed and eventually lower costs of milling are other favorable results of HSM [1].

HSM has been productively used also in fields where hardened tool steels are required, such as automotive and mould manufacturing of electronic pieces, glass industry, plastic, and metal mould making, casting, extrusion and drawing die in recent years. Various tool steels are used in the mould making industry. Hot work steels (AISI H series) which could work at temperatures between $315^{\circ} \mathrm{C}$ - $650^{\circ} \mathrm{C}$ are generally used in sheet mould making. Chrome-based AISI H13 and tungsten-based AISI H21 can be cited as examples to these steels. This kind of moulds are generally used at the levels of 45-56 HRC hardness. Cold work steels such as AISI P20, AISI P6, AISI O1, and AISI S7 are generally used for thermoplastics in plastic mould making. Fallböhmer et al. [2] reduced the value of $\mathrm{Rz}$ roughness of surface quality, which was formed as a result of HSM of hard materials such as cast iron and steel alloys used in mould manufacturing, into $5 \mu \mathrm{m}$. Vorasri et al. [3] carried out 54 different HSM processes on SKD 61 hot work steel material commonly used in mould making and obtained the lowest Ra roughness value as $0.08 \mu \mathrm{m}$. Alam et al. [4] Ti6Al4V processed titanium alloy through using small diameter tools at high speed and obtained Ra roughness value as $0.13 \mu \mathrm{m}$. Urbanski et al. [5] milled the hardened AISI H13 hot work tool steel at high speed and obtained Ra value lower than $1 \mu \mathrm{m}$. Toh [6] chose the hardened AISI H13 hot work tool steel and processed the surface via front milling and observed that the lowest roughness value was formed in the location where the contact field of the tool with workpiece was at the lowest level. Axinte and Dewes [7] milled the hardened AISI H13 hot work tool steel at high speed and determined the Ra surface roughness values between $0.36 \mu \mathrm{m}$ and $2.18 \mu \mathrm{m}$. Kasim et al. [8] optimized the surface roughness forming as a result of milling Inconel 718 alloy at high speed through using minimum quantity liquid (MQL) and measured the lowest roughness value as $0.117 \mu \mathrm{m}$. They observed that surface roughness was affected by radial feed and feed rate at most. Thangarasu and Sivasubramanian [9] milled AISI 304 stainless steel at high speed and measured the lowest roughness value as $2 \mu \mathrm{m}$. They also observed that the rising speed of surface roughness increased through 
feed per tooth and the depth of cut, and it decreased through an increase in the cutting speed $[10,11]$.

HSM technology was used and DIN 1.2344 hot work steel which was hardened at $51 \mathrm{HRC}$ hardness value was processed via $6 \mathrm{~mm}$-diameter spherical endmill through using different milling parameters as well as surface qualities which were obtained as a result of milling were examined in this study. Axial and radial feed values, feed value per tooth and depth of cut were changed between the range of 0.05 and $0.1 \mathrm{~mm}$ and the rate of cutting was changed between the range of $485 \mathrm{rpm}$ and $4000 \mathrm{rpm}$. These millings were carried out on material in the spherical form of which diameter was $21 \mathrm{~mm}$ and the central angle was $150^{\circ}$. Also, milling directions were processed in different ways as climb milling, conventional milling and bidirectional milling in experimental cuttings. Surface roughness was examined in directions with $15^{\circ}, 45^{\circ}, 75^{\circ}, 90^{\circ}, 105^{\circ}, 135^{\circ}$ and $165^{\circ}$ central angles on the material which was processed. The best surface quality was achieved in regions with $15^{\circ}$ and $45^{\circ}$ angles. In the case where the workpiece is bound through $15^{\circ}$ gradient via cutters with the spherical end and $0.02 \mathrm{~mm}$-feed is given, $\mathrm{Ra}$ surface roughness can be decreased into $3 \mu \mathrm{m}$.

\section{Material and Method}

\subsection{Work Piece}

DIN 1.2344 hot work steel is a material which is preferred in metal and plastic volume mould making. DIN 1.2344 hot work steel was chosen as experiment material in this study. This material became the reason for preference due to its advantages about ease of milling and surface quality after milling. Technical specifications of DIN 1.2344 hot work steel which was used in the experiments are shown in Table 1.

Table 1. Specifications and Chemical Analysis of Material DIN 1.2344 Used in The Experiment.

\begin{tabular}{|c|c|c|c|c|c|c|}
\hline $\begin{array}{l}\text { Material } \\
\text { Dimensions }\end{array}$ & \multicolumn{6}{|c|}{$80 \times 60 \times 40 \mathrm{~mm}$} \\
\hline Manufacturer & \multicolumn{6}{|c|}{ UDDEHOLM } \\
\hline Hardness & \multicolumn{6}{|c|}{ 51HRC } \\
\hline Symbol & \multicolumn{6}{|c|}{ X40CrMoV5-1 } \\
\hline $\begin{array}{l}\text { Manufacturer } \\
\text { Standard }\end{array}$ & \multicolumn{6}{|c|}{ ORVAR SUPREME } \\
\hline $\begin{array}{l}\text { DIN, ISO, } \\
\text { AISI } \\
\text { Description } \\
\end{array}$ & \multicolumn{6}{|c|}{$\begin{array}{ll}1.2344 & \text { W.-Nr. 1.2344. } \\
\text { AISI HI3 } & \end{array}$} \\
\hline $\begin{array}{l}\text { Chemical } \\
\text { Composition } \\
(\%)\end{array}$ & 0.39 & $\begin{array}{l}\mathbf{S i} \\
1.0\end{array}$ & 0.4 & $\begin{array}{l}\mathrm{Cr} \\
5.2\end{array}$ & $\begin{array}{l}\text { Mo } \\
1.4\end{array}$ & $\begin{array}{c}\mathbf{V} \\
0.9\end{array}$ \\
\hline
\end{tabular}

Three different milling strategies were used in the experiments from single cutting logic. Conventional Milling was applied on part A, Climb Milling was applied on part B, Bidirectional Milling was applied on part $\mathrm{C}$ upon the materials. Milling parts and milling directions are shown in Figure 1 and Figure 2. Other parameters used in the experiments are given in Table 2.

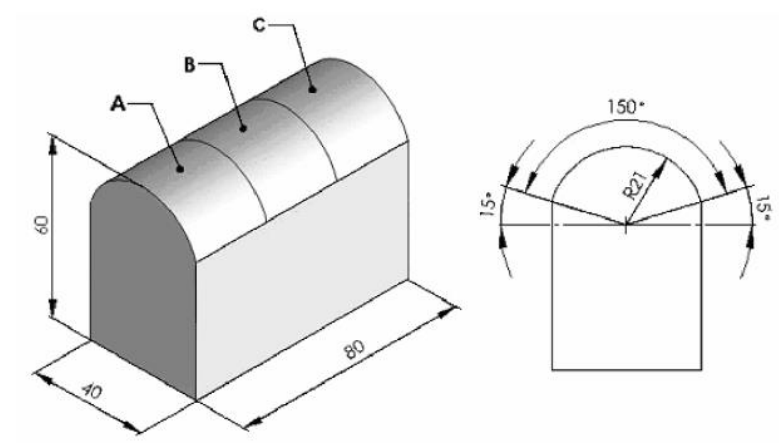

Figure 1. Shapes and Dimensions of Experimental Pieces.

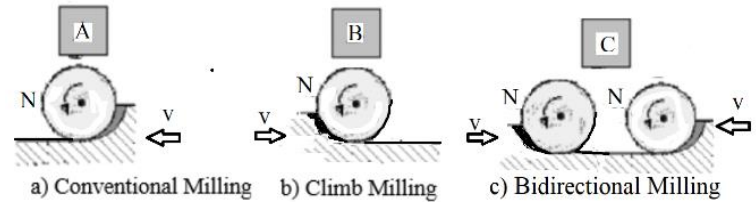

Figure 2. Experiment Milling Directions.

Table 2. Processing parameter ranges used in the experiments.

\begin{tabular}{|l|l|l|l|l|}
\hline Level & $\begin{array}{l}\text { ad } \\
(\mathbf{m m})\end{array}$ & $\begin{array}{l}\mathbf{a e} \\
(\mathbf{m m})\end{array}$ & $\mathbf{( m / z )}$ & $\begin{array}{l}\text { Vc } \\
(\mathbf{m} / \mathbf{m i n})\end{array}$ \\
\hline Minimum & 0.05 & 0.05 & 0.05 & 32.04 \\
Maximum & 0.1 & 0.1 & 0.1 & 263.89 \\
\hline
\end{tabular}

The experiments were conducted in the MATSUURA MC-550VX model linear-slide-vertical milling centre with FANUC 16IMB control unit which has the HSM capability. Finishing milling was carried out NIKKEN MBT40-GSK16C-90P (3B Lock High-Speed Slim Chuck) brand-tool chuck with high precision. Ra roughness values of the milled surfaces were measured via RUGOSURF surface roughness measurement device.

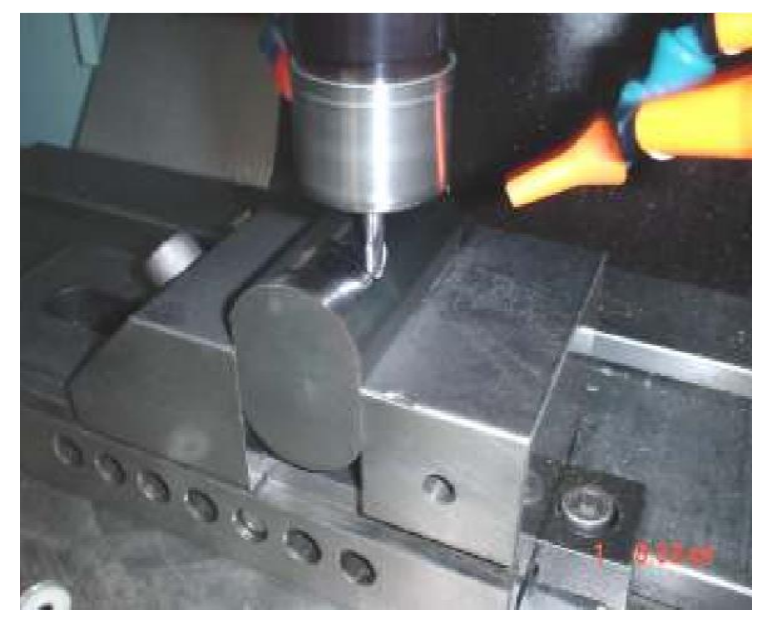

Figure 3. An Image from Experimental Studies. 


\section{Results and Discussion}

Milling times are seen to be equal in climb and conventional millings when Figure 3 is examined. Bidirectional cutting strategy substantially reduces the time. Milling time is not only specified by cutting strategy. Cutting speed and radial pass shots affect the total milling time as well. Although surface fields which were milled in the experiments were equal; $\mathrm{C}$ milling time of experiment 7 , in Table 3. was 1 minute, through the effects of cutting strategy, cutting feed and the effect of radial feed, the milling time in the A and B milling of the experiment 2 were 7 minutes and 2 seconds. Thus, a time difference of about 7 times occurred. Both surface quality and milling times have importance in mould making. Users should prefer minimum milling time or maximum surface quality. Milling parameters should be regulated by taking this demand into consideration. It should not be forgotten that high surface quality requires long milling times.

Table 3. Milling Times Acquired in The Experiments.

\begin{tabular}{|c|c|c|c|}
\hline Experiment & $\boldsymbol{R a}(\boldsymbol{A})(\mu \mathrm{m})$ & $\boldsymbol{R a}(\boldsymbol{B})(\mu \mathrm{m})$ & $\boldsymbol{R} \boldsymbol{a}(\boldsymbol{C})(\mu \mathrm{m})$ \\
\hline $\mathbf{1}$ & $5 \min 5 \mathrm{~s}$ & $5 \min 9 \mathrm{~s}$ & $3 \min 38 \mathrm{~s}$ \\
\hline $\mathbf{2}$ & $7 \min 2 \mathrm{~s}$ & $7 \min 2 \mathrm{~s}$ & $4 \min 05 \mathrm{~s}$ \\
\hline $\mathbf{3}$ & $2 \min 47 \mathrm{~s}$ & $2 \min 47 \mathrm{~s}$ & $1 \min 55 \mathrm{~s}$ \\
\hline $\mathbf{4}$ & $3 \min 44 \mathrm{~s}$ & $3 \min 44 \mathrm{~s}$ & $2 \min 03 \mathrm{~s}$ \\
\hline $\mathbf{5}$ & $2 \min 40 \mathrm{~s}$ & $2 \min 40 \mathrm{~s}$ & $1 \min 59 \mathrm{~s}$ \\
\hline $\mathbf{6}$ & $3 \min 38 \mathrm{~s}$ & $3 \min 38 \mathrm{~s}$ & $2 \min 01 \mathrm{~s}$ \\
\hline $\mathbf{7}$ & $1 \min 29 \mathrm{~s}$ & $1 \min 29 \mathrm{~s}$ & $1 \min$ \\
\hline $\mathbf{8}$ & $1 \min 57 \mathrm{~s}$ & $1 \min 57 \mathrm{~s}$ & $1 \min 05 \mathrm{~s}$ \\
\hline $\mathbf{9}$ & $5 \min 5 \mathrm{~s}$ & $5 \min 9 \mathrm{~s}$ & $3 \min 38 \mathrm{~s}$ \\
\hline $\mathbf{1 0}$ & $7 \min 2 \mathrm{~s}$ & $7 \min 2 \mathrm{~s}$ & $4 \min 05 \mathrm{~s}$ \\
\hline $\mathbf{1 1}$ & $2 \min 47 \mathrm{~s}$ & $2 \min 47 \mathrm{~s}$ & $1 \min 55 \mathrm{~s}$ \\
\hline $\mathbf{1 2}$ & $3 \min 44 \mathrm{~s}$ & $3 \min 44 \mathrm{~s}$ & $2 \min 03 \mathrm{~s}$ \\
\hline $\mathbf{1 3}$ & $2 \min 40 \mathrm{~s}$ & $2 \min 40 \mathrm{~s}$ & $1 \min 59 \mathrm{~s}$ \\
\hline $\mathbf{1 4}$ & $3 \min 38 \mathrm{~s}$ & $3 \min 38 \mathrm{~s}$ & $2 \min 01 \mathrm{~s}$ \\
\hline $\mathbf{1 5}$ & $1 \min 29 \mathrm{~s}$ & $1 \min 29 \mathrm{~s}$ & $1 \min$ \\
\hline $\mathbf{1 6}$ & $1 \min 57 \mathrm{~s}$ & $1 \min 57 \mathrm{~s}$ & $1 \min 05 \mathrm{~s}$ \\
\hline & & & \\
\hline
\end{tabular}

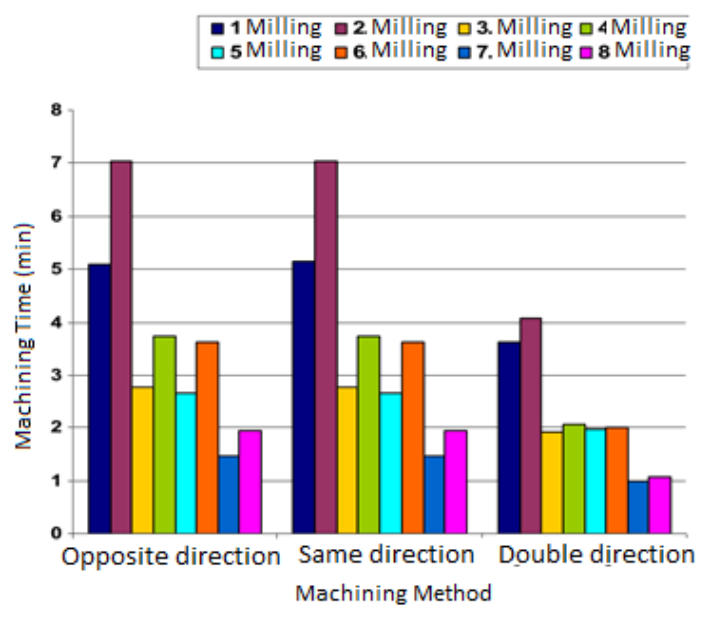

Figure 4. Milling Times Acquired Based on Milling Method.

It is seen that all the obtained surface parameters were at the values that had been aimed for a sensitive mould surface when the experimental data are examined. Values were below $1 \mu \mathrm{m}$ in all data. The surface roughness values which were obtained in other studies conducted with the same aim are at the ranges of $0.1 \mu \mathrm{m} \mathrm{Ra}$ [12], $0.18 \mu \mathrm{m} \mathrm{Ra}, 0.10 \mu \mathrm{m}$ Ra [13], 0.30-0.45 $\mu \mathrm{m}$ Ra [14], $0.30-0.45 \mu \mathrm{m} \mathrm{Ra}[15]$. It is seen that this study improved and contributed to the studies on this subject through the values obtained at the range between 0.08 and $0.7 \mu \mathrm{m}$ Ra. Another feature of the study which was conducted is semicircle geometry that was used in milling. Planar surfaces have been generally used in experimental studies on HSM. As it is known, surface roughness values which were obtained in the grinding process are at the range between 0.025 and $6.3 \mu \mathrm{m}$ [16]. It is possible to obtain roughness values of a surface which was ground via HSM when the results obtained are examined. Roughness values are generally close in conventional milling (A), climb milling (B) and bidirectional milling (C), when Table 4 where there are experiment parameters and surface roughness values obtained is examined [17]. In general, surface quality in bidirectional machining is lower than other strategies. 
Table 4. Experiment Parameters Used Based on Milling Order and Average Surface Roughness Values Obtained.

\begin{tabular}{|c|c|c|c|c|c|c|c|c|c|c|c|}
\hline $\begin{array}{c}\text { Expe } \\
\text { rime } \\
\text { nt }\end{array}$ & $\begin{array}{c}a d \\
(m m)\end{array}$ & $\begin{array}{c}a e \\
(m m)\end{array}$ & $\begin{array}{c}f z \\
(m / z)\end{array}$ & $\begin{array}{c}V c \\
M a x \\
(m / m i \\
n)\end{array}$ & $\begin{array}{c}V c \\
M i n \\
(m / m i \\
n)\end{array}$ & $\begin{array}{c}n \\
(\text { rev/min } \\
\quad)\end{array}$ & $\begin{array}{c}F \\
(m m / m i \\
n)\end{array}$ & $\begin{array}{c}\text { Deff } \\
(\mathrm{mm})\end{array}$ & $\begin{array}{c}\boldsymbol{R a}(\boldsymbol{A} \\
) \\
(\mu \mathrm{m})\end{array}$ & $\begin{array}{c}\boldsymbol{R a}(\boldsymbol{B} \\
) \\
(\mu m)\end{array}$ & $\begin{array}{r}\operatorname{Ra}(\boldsymbol{C}) \\
(\mu \mathrm{m})\end{array}$ \\
\hline 1 & 0.05 & 0.05 & 0.05 & 263.89 & 44.86 & 14.000 & 1.400 & 1.02 & 0.21 & 0.20 & 0.28 \\
\hline 2 & 0.05 & 0.05 & 0.05 & 188.50 & 32.04 & 10.000 & 1.000 & 1.02 & 0.22 & 0.25 & 0.27 \\
\hline 3 & 0.05 & 0.05 & 0.1 & 263.89 & 44.86 & 14.000 & 2.800 & 1.02 & 0.25 & 0.26 & 0.35 \\
\hline 4 & 0.05 & 0.05 & 0.1 & 188.50 & 32.04 & 10.000 & 2.000 & 1.02 & 0.29 & 0.27 & 0.34 \\
\hline 5 & 0.05 & 0.1 & 0.05 & 263.89 & 44.86 & 14.000 & 1.400 & 1.02 & 0.19 & 0.18 & 0.32 \\
\hline 6 & 0.05 & 0.1 & 0.05 & 188.50 & 32.04 & 10.000 & 1.000 & 1.02 & 0.20 & 0.24 & 0.34 \\
\hline 7 & 0.05 & 0.1 & 0.1 & 263.89 & 44.86 & 14.000 & 2.800 & 1.02 & 0.40 & 0.40 & 0.53 \\
\hline 8 & 0.05 & 0.1 & 0.1 & 188.50 & 32.04 & 10.000 & 2.000 & 1.02 & 0.33 & 0.33 & 0.49 \\
\hline 9 & 0.1 & 0.05 & 0.05 & 263.89 & 44.86 & 14.000 & 1.400 & 1.44 & 0.20 & 0.19 & 0.23 \\
\hline 10 & 0.1 & 0.05 & 0.05 & 188.50 & 32.04 & 10.000 & 1.000 & 1.44 & 0.15 & 0.14 & 0.23 \\
\hline 11 & 0.1 & 0.05 & 0.1 & 263.89 & 44.86 & 14.000 & 2.800 & 1.44 & 0.25 & 0.28 & 0.38 \\
\hline 12 & 0.1 & 0.05 & 0.1 & 188.50 & 32.04 & 10.000 & 2.000 & 1.44 & 0.25 & 0.26 & 0.39 \\
\hline 13 & 0.1 & 0.1 & 0.05 & 263.89 & 44.86 & 14.000 & 1.400 & 1.44 & 0.21 & 0.25 & 0.35 \\
\hline 14 & 0.1 & 0.1 & 0.05 & 188.50 & 32.04 & 10.000 & 1.000 & 1.44 & 0.24 & 0.27 & 0.34 \\
\hline 15 & 0.1 & 0.1 & 0.1 & 263.89 & 44.86 & 14.000 & 2.800 & 1.44 & 0.26 & 0.31 & 0.43 \\
\hline 16 & 0.1 & 0.1 & 0.1 & 188.50 & 32.04 & 10.000 & 2.000 & 1.44 & 0.30 & 0.36 & 0.39 \\
\hline
\end{tabular}

Optimum surface roughness is obtained, in the case where contact angles of tools and workpiece are between 15 and 20 degrees in plane surface milling (Table 5). Contact angle constantly changes, and the forming surface qualities indicate a different value in parallel with this situation when the circular surface form used in this study is taken into consideration. Roughness graphs have been drawn based on the experiment order by using roughness data obtained in the experiments and shown in Table 5 (Figure 4 and 5).

Table 5. Surface Roughness Values Obtained for Measurement Points Detected as a Result of Millings.

\begin{tabular}{ccccccccccccccccc}
\hline \multirow{2}{*}{ Experiment } & \multicolumn{1}{c}{$\boldsymbol{R} \boldsymbol{a}(\boldsymbol{A})(\boldsymbol{\mu m})$} \\
\cline { 2 - 5 } & $15^{\circ}$ & $45^{\circ}$ & $75^{\circ}$ & $90^{\circ}$ & $105^{\circ}$ & $135^{\circ}$ & $165^{\circ}$ & $15^{\circ}$ & $45^{\circ}$ & $75^{\circ}$ & $90^{\circ}$ & $105^{\circ}$ & $135^{\circ}$ & $165^{\circ}$ \\
$\mathbf{1}$ & 0.28 & 0.22 & 0.21 & 0.23 & 0.17 & 0.16 & 0.20 & 0.21 & 0.15 & 0.19 & 0.13 & 0.10 & 0.18 & 0.41 \\
$\mathbf{2}$ & 0.39 & 0.19 & 0.16 & 0.17 & 0.18 & 0.11 & 0.34 & 0.33 & 0.13 & 0.26 & 0.19 & 0.21 & 0.22 & 0.38 \\
$\mathbf{3}$ & 0.26 & 0.30 & 0.17 & 0.19 & 0.25 & 0.28 & 0.29 & 0.24 & 0.26 & 0.28 & 0.14 & 0.30 & 0.29 & 0.33 \\
$\mathbf{4}$ & 0.39 & 0.28 & 0.35 & 0.25 & 0.24 & 0.21 & 0.30 & 0.21 & 0.21 & 0.33 & 0.26 & 0.23 & 0.20 & 0.42 \\
$\mathbf{5}$ & 0.19 & 0.19 & 0.23 & 0.10 & 0.18 & 0.21 & 0.21 & 0.13 & 0.14 & 0.27 & 0.11 & 0.17 & 0.25 & 0.17 \\
$\mathbf{6}$ & 0.16 & 0.16 & 0.20 & 0.18 & 0.24 & 0.25 & 0.19 & 0.18 & 0.13 & 0.24 & 0.14 & 0.45 & 0.23 & 0.30 \\
$\mathbf{7}$ & 0.52 & 0.39 & 0.38 & 0.55 & 0.35 & 0.31 & 0.30 & 0.50 & 0.33 & 0.34 & 0.38 & 0.53 & 0.39 & 0.30 \\
$\mathbf{8}$ & 0.56 & 0.24 & 0.29 & 0.23 & 0.42 & 0.31 & 0.28 & 0.42 & 0.28 & 0.31 & 0.13 & 0.43 & 0.26 & 0.50 \\
$\mathbf{9}$ & 0.16 & 0.36 & 0.24 & 0.10 & 0.22 & 0.17 & 0.16 & 0.13 & 0.30 & 0.33 & 0.06 & 0.28 & 0.15 & 0.09 \\
$\mathbf{1 0}$ & 0.14 & 0.09 & 0.21 & 0.19 & 0.22 & 0.10 & 0.08 & 0.11 & 0.14 & 0.23 & 0.10 & 0.22 & 0.08 & 0.10 \\
$\mathbf{1 1}$ & 0.39 & 0.39 & 0.21 & 0.17 & 0.16 & 0.21 & 0.32 & 0.47 & 0.42 & 0.24 & 0.17 & 0.20 & 0.17 & 0.30 \\
$\mathbf{1 2}$ & 0.32 & 0.23 & 0.20 & 0.30 & 0.29 & 0.10 & 0.30 & 0.18 & 0.38 & 0.36 & 0.21 & 0.29 & 0.19 & 0.24 \\
$\mathbf{1 3}$ & 0.19 & 0.24 & 0.29 & 0.22 & 0.20 & 0.17 & 0.14 & 0.23 & 0.28 & 0.37 & 0.31 & 0.17 & 0.22 & 0.17 \\
$\mathbf{1 4}$ & 0.31 & 0.24 & 0.14 & 0.25 & 0.35 & 0.21 & 0.21 & 0.28 & 0.32 & 0.25 & 0.31 & 0.25 & 0.26 & 0.19 \\
$\mathbf{1 5}$ & 0.26 & 0.24 & 0.15 & 0.34 & 0.41 & 0.20 & 0.25 & 0.35 & 0.35 & 0.26 & 0.38 & 0.27 & 0.19 & 0.34 \\
$\mathbf{1 6}$ & 0.16 & 0.17 & 0.18 & 0.19 & 0.20 & 0.21 & 0.22 & 0.23 & 0.24 & 0.25 & 0.26 & 0.27 & 0.28 & 0.29 \\
\hline
\end{tabular}




\begin{tabular}{cccccccc}
\hline \multirow{2}{*}{ Experiment } & \multicolumn{7}{c}{ Ra $(\mathbf{C})(\boldsymbol{\mu m})$} \\
\cline { 2 - 8 } $\mathbf{1}$ & $15^{\circ}$ & $45^{\circ}$ & $75^{\circ}$ & $90^{\circ}$ & $105^{\circ}$ & $135^{\circ}$ & $165^{\circ}$ \\
$\mathbf{2}$ & 0.42 & 0.24 & 0.23 & 0.27 & 0.16 & 0.17 & 0.46 \\
$\mathbf{3}$ & 0.27 & 0.14 & 0.28 & 0.20 & 0.31 & 0.30 & 0.35 \\
$\mathbf{4}$ & 0.37 & 0.36 & 0.33 & 0.42 & 0.36 & 0.35 & 0.29 \\
$\mathbf{5}$ & 0.38 & 0.27 & 0.34 & 0.45 & 0.30 & 0.31 & 0.32 \\
$\mathbf{6}$ & 0.50 & 0.20 & 0.40 & 0.23 & 0.48 & 0.26 & 0.17 \\
$\mathbf{7}$ & 0.38 & 0.22 & 0.36 & 0.19 & 0.34 & 0.48 & 0.44 \\
$\mathbf{8}$ & 0.46 & 0.62 & 0.64 & 0.50 & 0.63 & 0.42 & 0.44 \\
$\mathbf{9}$ & 0.55 & 0.44 & 0.42 & 0.50 & 0.55 & 0.52 & 0.44 \\
$\mathbf{1 0}$ & 0.22 & 0.14 & 0.30 & 0.20 & 0.32 & 0.21 & 0.20 \\
$\mathbf{1 1}$ & 0.19 & 0.20 & 0.23 & 0.26 & 0.32 & 0.18 & 0.20 \\
$\mathbf{1 2}$ & 0.56 & 0.28 & 0.32 & 0.67 & 0.31 & 0.25 & 0.30 \\
$\mathbf{1 3}$ & 0.31 & 0.42 & 0.45 & 0.60 & 0.34 & 0.30 & 0.29 \\
$\mathbf{1 4}$ & 0.40 & 0.40 & 0.23 & 0.44 & 0.42 & 0.30 & 0.29 \\
$\mathbf{1 5}$ & 0.34 & 0.36 & 0.26 & 0.46 & 0.46 & 0.28 & 0.19 \\
$\mathbf{1 6}$ & 0.37 & 0.46 & 0.40 & 0.54 & 0.36 & 0.28 & 0.57 \\
\hline
\end{tabular}

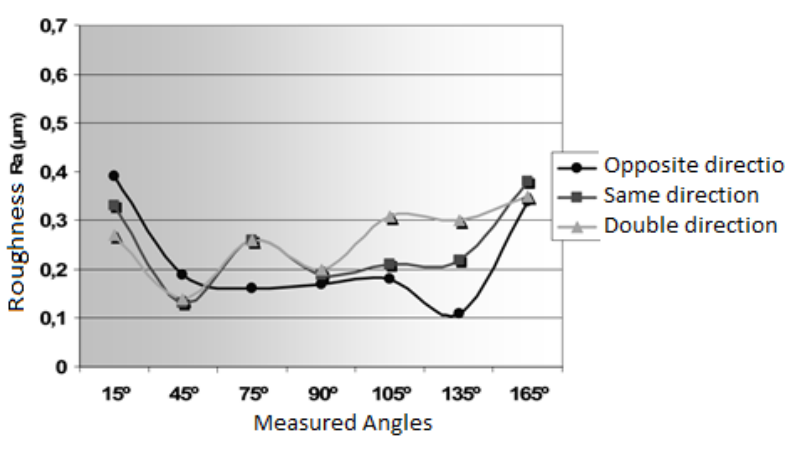

Figure 5. Roughness Values Acquired in the First Experiment.

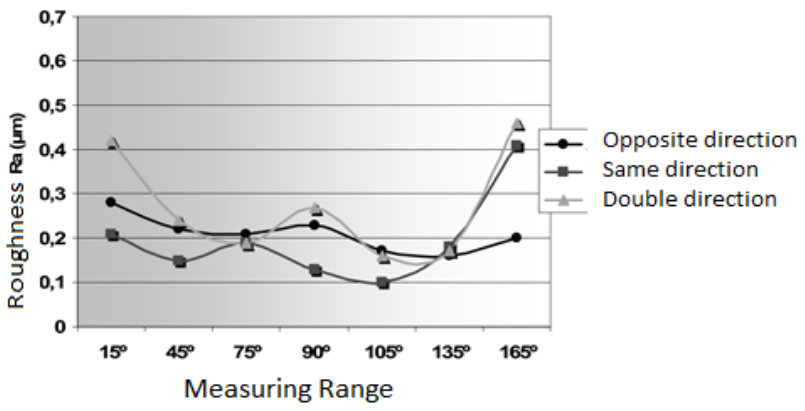

Figure 6. Roughness Values Acquired in the Second Experiment.

\section{Conclusions}

A lot of better surface quality and measurement sensitivity can be achieved in a shorter notice via HSM technology than the traditional milling. Surface qualities forming as a result of Climb Milling and Conventional Milling indicated a parallel result with minor differences when the experiment graphs were examined. More sufficient surface quality is generally achieved via climb milling strategy for finish processes in comparison with the other strategies.

Sensitive measurement tolerances and surface roughness values are important in mould manufacturing; therefore, it is impossible to complete mould manufacturing on a single bench through traditional methods. Final mould form can be significantly achieved in HSM technology and the processes required for surface polishing after milling are generally removed.

- As seen in the experiment data, surface qualities were at optimum angles between $15^{\circ}$ and $45^{\circ}$ on both sides.

- The amount of the removed chips is another factor that has an effect on surface quality. The less the amount of chips left for the finishing process, the higher the surface sensitivity level is.

- Plane surfaces in a vertical position to the axis of tools should be milled via tools with the spherical end as far as possible. Because; cutting speed is zero on the pole end of tools with the spherical end and thus, not cutting but scraping process will be performed in this part contacting with the workpiece. Therefore, milling qualities of this kind of surfaces will not be substantial. From this point of view, the fact that tools work in a way that they form even a minor angle with the workpiece increases the effective diameter of tools and cutting speed and so, a better surface quality will be achieved, and the lifespan of tools will increase.

- The best and homogeneous surface roughness can be achieved in cases where axial and radial feed is kept equal when working time is kept stable. The fact that the surface roughness is the same within both directions makes the polishing process easier after milling. The lower these two values are chosen, the 
more the surface quality gets sensitive. However, this case causes milling time to extend.

- It is possible to reduce Ra surface roughness into 0,03 $\mu \mathrm{m}$ via cutters with the spherical end if the workpiece is bound curvedly with an angle at $15^{\circ}$ and $0.02-\mathrm{mm}$ feed is applied [4]. This sensitivity level is a productive value for all mould making applications.

- HSM milling can be conducted without a big burden on the tools when the amount of the removed chips is low. Geometry and dimensions of chip forming in HSM are at much smaller sizes than traditional milling. This feature causes the temperature arising in the removal of the chip to be lower than traditional methods as well as the lifespan of tools to extend. Thermal deformations and expansion which might be formed in the material due to temperature are hindered.

- Binding length of tools have an effect on the forming surface quality in HSM. Ideal L/D rate is $3 \sim 5$ for high speed. The more the binding length is short, the more the stretch of tools decreases.

- High level of milling tolerance positively affects the surface quality and has an extending effect on milling time.

\section{Author's Contributions}

Ayhan Etyemez: Assisted in analytical analysis on the structure, supervised the experiment's progress, result interpretation and helped in manuscript preparation.

Aziz Baran: Drafted and wrote the manuscript, performed the experiment and result analysis.

\section{Ethics}

This article is composed of the master's thesis of Aziz Baran, under the supervision of Ayhan Etyemez. There is no conflict of interest.

\section{References}

1. Dewes, R.C., Aspinwall, D.K. 1996. A review of ultra highspeed milling of hardened steels. Journal of Materials Processing Technology; 69: 1-17.

2. Fallböhmer, P., Rodriguez, C. A., Özel. T., Altan, T. 2000. Highspeed machining of cast iron and alloy steels for die and mold manufacturing. Journal of Materials Processing Technology; 98: 104-115

3. Vorasri, M., Jirapattarasilp, K., Kaewkuekool, S. 2011. The effect of high-speed milling on surface roughness of hardened tool steel, World Academy of Science, Engineering and Technology; 59: 469472.

4. Alam, S., Amin, A. N., Patwari, A. U. 2010. Surface texture investigation in high speed flat end milling of Ti-6Al-4V. International Conference on Industrial Engineering and Operations Management Dhaka, Bangladesh, January 9-10, 2010.

5. Urbanski, J. P., Koshy, P., Dewes, R. C., Aspinwall, D. K. 2000 High speed machining of moulds and dies for net shape manufacture. Materials and Design; 21: 395-402.
6. Toh, C. K. 2002. Surface topography analysis in high speed finish milling inclined hardened steel. Precision Engineering; 28: 386398.

7. Axinte, D. A., Dewes, R. C. 2002. Surface integrity of hot work tool steel after high speed milling-experimental data and empirical models. Journal of Material Processing Technology; 127: 325-335.

8. Kasim, M. S., Che Haron, C. H., Ghani, J.A., Sulaiman, M.A. 2013. Prediction surface roughness in high-speed milling of inconel 718 under mql using rsm method. Middle-East Journal of Scientific Research; 13 (3): 264-272.

9. Thangarasu, V. S., Sivasubramanian, R. 2012. High speed cnc machining of AISI 304 stainless steel; optimization of process parameters. International Journal of Mechanical Engineering and Robotics Research; 1 (3): 9-21.

10. Baran, A. 2006. Sertleştirilmiş Kalıp Çeliklerinin Yüksek Hızda İşlenmesinde Uygun Kesme Parametrelerinin Seçimi. M. Ü. F. B. E. Yüksek Lisans Tezi.

11. Yang Z., Xue Y., Li Y. Xu J., Wang Q. 2018. The effect of milling parameters on surface integrity in high-speed milling of ultrahigh strength steel. Procedia CIRP; 71:83-88

12. Schulz, H., Moriwaki, T. 1992. High speed machining. Ann. CIRP; 41(2):637- 643 .

13. Nakagawa, T., 1992. Emerging new technologies in milling. 7th International Conference of Tool, Die and Mold Industry International Special Tooling Association, Bergamo, Italy;85

14. Kauppinen, V., Paro J., Nieminen I. Application of high-speed milling to the finish manufacturing industry. Helsinki University of Technology, Technical Research Center of Finland, Espoo, Finland, 1993, pp 83

15. Eversheim, W., König, W., Bieker, R., Cobanoglu, M. 1989. Nc - frasbearbeitung on vergüteten schmiedegesenken. Technology \& Engineering; 86: 99-103

16. Field, M., Kahles, J. F., Koster, W. P. Surface Finish and Surface Integrity. ASM Handbook, Metcut Research Associates Inc., USA, 1980; pp $18-87$.

17. Vivancos, J., Luis, C.J., Costa, L., Ortiz, J.A. 2004. Optimal Machining Parameters Selection in High Speed Milling of Hardened Steels for Injection Molds. Journal of Material Processing Technology; pp 155-156:1505-1512. 